\title{
Status of ecotourism in Nepal: a case of Bhadaure-Tamagi village of Panchase area
}

\author{
Ramesh Neupane $^{1} \cdot$ Anup K C $^{2,3}$ D $\cdot$ Manoj Aryal $^{4} \cdot$ Kedar Rijal $^{1}$
}

Received: 19 July 2020 / Accepted: 27 February 2021 / Published online: 15 March 2021

(c) The Author(s), under exclusive licence to Springer Nature B.V. 2021

\begin{abstract}
This study was conducted with an aim to assess the status of ecotourism in terms of tourism demand, tourist characteristics, and strength, weakness, opportunity, and threat (SWOT) analysis. For this, the study was conducted in Bhadaure-Tamagi village of the Panchase Protected Forest Area of Gandaki Province, which was planned to be developed as an important tourist destination for tourists visiting Pokhara because of its cultural and natural importance. Mixed-method research approach was implemented in this research for data collection and analysis. One hundred and twenty-two tourism stakeholders (30 hoteliers, 40 homestay owners, and 52 tourists) were surveyed for quantitative data collection and analysis along with seven key informant interviews (KII) for qualitative data collection and analysis. It was observed that the current demand for accommodation facilities in the Bhadaure-Tamagi village was 23,390 bed nights per annum. The tourism demand in terms of tourism revenues estimated through this study amounted to a total of US\$10,763.67 per year. The occupancy rate of accommodation facilities at Bhadaure-Tamagi village was a mere $20 \%$, which is well below the national and international average. Despite outstanding ecotourism opportunities and a necessary regulatory framework in place, the SWOT analysis revealed that the tourism sector development is not satisfactory. In the current situation, Coronavirus disease (COVID-19) had adversely affected the ecotourism in the area. So, tourism promotional activities need to be focused by following appropriate health, hygiene, and safety measures.
\end{abstract}

Keywords Ecotourism · Tourism demand · Accommodation capacity $\cdot$ SWOT analysis · Panchase

Anup K C

kcanup04@gmail.com

1 Central Department of Environmental Science, Tribhuvan University, Kirtipur, Kathmandu, Nepal

2 Department of Parks Recreation and Tourism Management, Clemson University, Clemson, SC, USA

3 Department of Environmental Science, Amrit Campus, Tribhuvan University, Kathmandu, Nepal

4 Ministry of Physical Infrastructure and Transport, Department of Roads, Government of Nepal, Kathmandu, Nepal 


\section{Introduction}

Tourism is one of the rapidly growing largest sectors of the world economy, contributing 10\% of global Gross Domestic Product (GDP), 7\% of international exports, and representing one job for every ten employment options globally \{The United Nations Environment Program (UNEP, 2020) \}. Ecotourism is one of the crucial components of this industry (K C, 2017). The number of foreign tourists around the world increased by $4 \%$ in 2019, reaching 1.5 billion following a world economic rise and increased tourism demand \{The World Tourism Organization (UNWTO, 2020)\}. It has the potential to increase investment, jobs, exports, and technologies in the least developed and small island countries while inflicting just minimal adverse environmental impacts (UNEP, 2020). Current practices of linking local communities and the environment with ecotourism play a significant role in reducing climatic problems and attaining development goals (K C \& Thapa Parajuli, 2015a, b).

The definition of ecotourism varies in terms of its scope, criteria used, and aspects of its planning and operation (Diamantis, 1999). Despite the variance, ecotourism definitions primarily focus on conserving the environment, reducing environmental impacts, and involving the local community and its economy. It supports environmental conservation and sustainable development of affected people (Atun et al., 2019). Ecotourism has also been implemented to tackle poverty and biodiversity loss (Timmer \& Juma, 2005).

\subsection{Tourism demand and accommodation capacity}

Tourism demand is a broad term that involves size, characteristics, types of need, and reasons for making such demand. It differs with variation in the site (Schirpke et al., 2020). As world income continues to grow, and countries develop, tourism demand should be expected to increase (Yamaura \& Thompson, 2015). Therefore, in terms of economics, tourism demand is driven by the tourists' willingness to pay for tourism goods and services, which depends on the place of origin, the value of the product in destination, prices of the same products at similar destinations, and the effect of singular incidents (Song et al., 2010). The most common method of estimating tourism demand is estimating tourist arrivals, while some other ways estimate tourist expenditure and the number of nights spent at the tourist destination. For example, Okayasu (2008) measured the tourism demand of the Eastern Arc Mountains of Tanzania based on the tourist arrival data collected from hotels, local guides, and the protected areas within the Eastern Arc Mountains through hotel guest books, tourism office visitor books, and protected area registers. Likewise, in the study report called 'Tourism Strategy and Action Plan for the Prespa Lakes Basin 2012-2016', Travers \& LaPaz (2012) assessed the global, regional, and local tourism demand based on the tourism arrival and tourism receipt data from UNWTO (2011).

Accommodation capacity is the total number of accommodations available in the region. Popescu \& Plesoianu (2017) define it as the number of beds/places that are meant for accommodating tourists. Sometimes, preferably an average accommodation capacity is measured, which is the total number of beds divided by the total number of accommodations (Ouerfelli, 2008). Accommodation capacity is necessary for the tourism administrators to know visitors' characteristics for the proper management of tourist destinations (Dickman, 1989). In remote areas, it will help tourism entrepreneurs to manage goods according to the requirement of tourists. Also, the effect of tourism on regional development is also shown by an area's accommodation capacity (Soukiazis \& Proença, 2008). 
Bălăcescu \& Răbonţu (2010) carried out the statistical analysis of the touristic accommodation capacity and activity of Romania from the period of 2000 to 2009 based on the touristic accommodation capacity data across various types of accommodation facilities in Romania collected by the National Institute of Statistics. Similarly, Sedai (2013) assessed accommodation capacities of 15 major and 5 minor tourist sites of Nepal based on the relevant secondary sources when they were available. For those sites for which secondary data were not available, accommodation enterprise surveys were conducted for primary data.

\subsection{Characteristics of tourists}

Characteristics of tourists influence the preference of information sources, such as the internet, friends, travel agents, or destination sources, while also affecting the formation of tourism destination image (Beerli \& Martin, 2004). The characteristics of tourists also help in establishing the link between the socio-demographics of tourists with certain tourism products. For example, in a study by Peršurić \& Težak (2009), there were significant correlations between the socio-demographics of tourists and their interest in organically produced foods. Apart from that, tourists' characteristics have found a utility in online tourism products advertising, thereby improving the tourism businesses through targeted advertising to tourists who visit travel and tourism websites (Hernández-Méndez \& Muñoz-Leiva, 2015).

The number of variables to be surveyed for studying the characteristics of tourists visiting a particular destination depends on the type of study as well as the destination itself being studied. Hadi \& Prasetyo (2020) carried out a study on tourism characteristics of Rammang-Rammang Limestone Forest Park in Indonesia based on gender, age, status, profession, latest educational qualification, frequency of visits, total expenditure, length of stay, and motivation for a visit. Similarly, Silva et al. (2020) analyzed the shopping behavior of international tourists collecting the response through a questionnaire survey of 278 respondents based on variables for tourist characteristics like shopping motives, travel activities, age, income, family size, accommodation type, and length of stay. Chuan \& Weng (2010) used the logbook entry at Tabing Hide, one of six salt lick hides around Kuala Tahan, Malaysia, for data collection about tourist characteristics where the study was concentrated on behavioral and demographic patterns of wildlife visitors, like the visitors' comments on the logbook and its categorization by the number and frequency of mentions of wildlife species, the nationality of visitors, the month of visit as well as qualitative analysis of visitors' comments as wildlife watchers vs. fun-seekers.

\subsection{SWOT analysis}

SWOT analysis is a technique used to assess the status and prospects of businesses. This model is a strategic tool to identify the inner system's strengths and weaknesses with opportunities and threats to the external network (Dong et al., 2015; Ganjali, 2014; Iliopoulou-Georgudaki et al., 2017; Nikolaou \& Evangelinos, 2010). The selection of an appropriate SWOT strategy maximizes the strengths and opportunities and minimizes the weaknesses and threats (Bhatia, 2013; Nikolaou \& Evangelinos, 2010). SWOT analysis helps to identify the impact of the economic, political, and social sectors of the environment and draws top management's attention to the firm's strategy and critical aspects of its operations (Bhatia, 2013). This technique has been used in yacht-based tourism (Sariisik et al., 
2011) and rural tourism (Akça, 2006). However, it is not possible to accurately aggregate ecotourism's contribution either to socio-economic development or conservation.

Collins-Kreiner \& Wall (2007) observed that SWOT analysis helps local decision-makers identify potential benefits and threats to their development in Western Negev, Southern Israel. Findings of Sayyed et al. (2013) in Tandooreh National Park (NE Iran) and Akbulak \& Cengiz (2014) in Troia Historical National Park (Turkey) show that SWOT analysis is essential for finding choices for the strategic management of sustainable ecotourism. The SWOT analysis also helped identify strategic management options and assess the environmental sustainability of Penang National Park (Hong \& Chan, 2010). Inappropriate SWOT strategies may lead to the failure of ecotourism projects focused on sustainable landscapes and livelihoods in the Kimbi Game Reserve (Neba, 2009). Zhuang et al. (2011) observed that the success of the ecotourism project is only possible through a collaborative and iterative effort through a long period of time resulting in economic and environmental benefits for rural areas in an ecotourism demonstration project in the Laojunshan area of northwestern Yunnan Province in western China.

To get optimum benefits from the sports activities, the SWOT analysis by Moosavi et al. (2013) in West Mazandaran of Iran recommended that tourism managers should integrate ecotourism potentials and opportunities. The findings of Murugan (2007) in Puducherry show that SWOT analysis is strategic in the planning process and highlights essential areas and clear direction to the ecotourism planning efforts. The study of Mbaiwa (2010) in the Makgadikgadi Framework Management Plan (MFMP) Area concluded that different types of tourism approaches are applicable in the wetland. Beeler (2000) observed that a single export economy's weaknesses and limited-produced goods in Venado Island of Costa Rica could be decreased by creating new markets for ecotourism development. In the case of natural places of Nepal like the Panchase area, not enough SWOT analyses have been conducted in researches of ecotourism at three different levels (viz. local, regional, and national level) to identify the potential avenues and obstacles as well as strategies for ecotourism development of the region.

Due to the rich natural, religious, cultural, and aesthetic resources in the Panchase area, it can be a vital tourism destination adjoining Pokhara (Adhikari et al., 2018). Similar to most other nature-based tourism destinations of Nepal, it is particularly popular for short trekking in addition to pilgrimage tourism by devotees during Bala Chaturdashi festival. However, very few studies have been conducted on ecotourism's status to identify tourism destinations, visitors' characteristics, tourism demand, and accommodation capacity of attractions in the Panchase area. Also, SWOT analysis to identify policies and strategies for enhancing ecotourism business performance in Bhadaure-Tamagi village of Panchase is essential. Therefore, this study attempts to fill this knowledge gap by identifying the priority tourism destinations within the village, determining its tourism demand and accommodation capacity, and exploring its strengths, weaknesses, opportunities, and threats to highlight its current role and bring its potentials into the light. It is also necessary to highlight the current state of tourism at the time of the COVID-19 pandemic.

\section{Study area}

The study site, Panchase area, lies in the boundaries of three districts (Kaski, Parbat, and

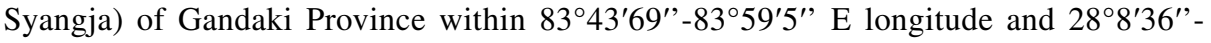
$28^{\circ} 18^{\prime} 17^{\prime \prime}$ N latitude (Adhikari et al., 2018). 'Panchase,' which means 'Five Seats', is 

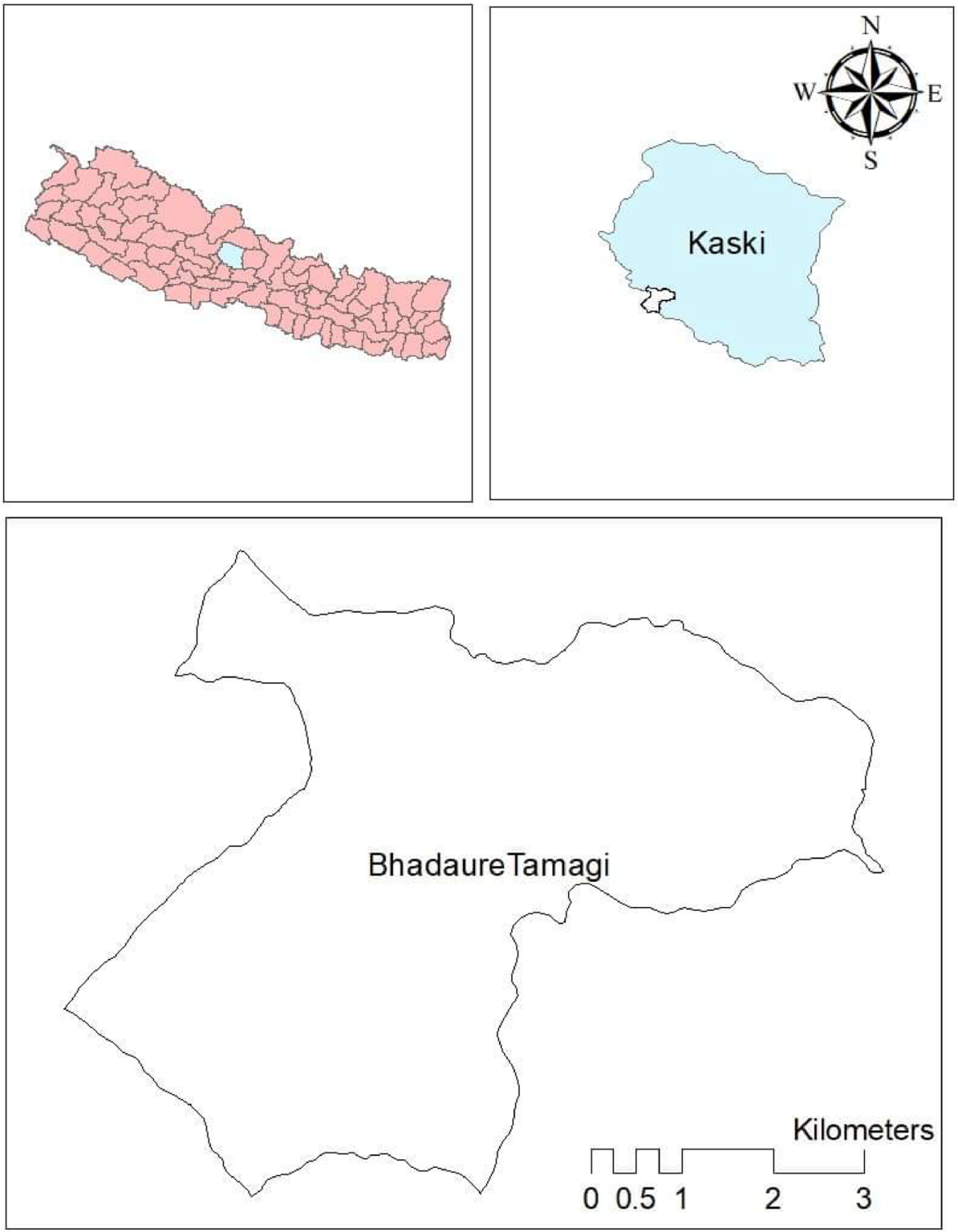

Fig. 1 Location map of study site

the meeting place of five peaks which offers a scenic view of the Annapurna Range's mountains. Among the 17 villages that lie in Panchase Area, Bhadaure-Tamagi village was taken for study, which is the largest village among other villages with a relatively higher concentration of ecotourism activities with an area of 2504.26 ha as shown in Fig. 1 (Sharma et al., 2013). Bhadaure Deurali, Talibarang, and Tamagi villages can be accessed through the Kande in Pokhara-Baglung Highway, from where the road to Panchase starts. This route is about $30 \mathrm{~km}$ from Pokhara and takes around 2 hours to reach 
via jeep. Additional 4 hours is required to trek to the peak of the Panchase hill. Another popular route is to take a public bus to Ghatichinna/Bhanjyang from Pokhara, which passes through Paame. And from Ghatichinna, one can then opt to trek along the gravel road or take a relatively shorter route through narrow stone trails that cross the tortuous highway at several points, to Bhanjyang via Damdame and Sidhane. Another way to reach Panchase Area from Pokhara is through Dimuwa in Pokhara-Baglung Highway, leading to Ramja Deurali and Chitre village of Parbat district. It is a 4-h trek from Chitre to Panchase Peak. Some people take a vehicle ride from Pokhara along Siddhartha Highway to Bange Phadke, Arthar Hill, and Arukharka and then trek to Panchase Peak. Panchase area is one of the important natural areas where ecotourism development was realized for the site's socio-economic transformation where the local people inhabit. Ecotourism has a tremendous effect, and its potential remains less tapped for the development of the place. However, it has unparalleled natural attractions, fantastic mountain landscapes, and biodiversity \{International Union for Conservation of Nature (IUCN, 2014)\}. It is considered by the Master Plan for the Development of Rural Tourism in the Panchase area as a popular tourist attraction \{Tara Gaon Development Board (TGDB, 2004)\}.

\section{Methodology}

Necessary information on available tourism sites in Bhadaure-Tamagi village was collected from Nepal Tourism Board (NTB) and Panchase Protected Forest Office in Pokhara, and a list of potential tourist attractions was identified. The preliminary field visit was conducted in October 2013, and the initial field visit for data collection was conducted from May to June 2014, and October and December of 2014. Later, to obtain the information after Coronavirus disease (COVID-19), the phone interviews were conducted in October 2020. A mixed-method approach was used for primary data collection and analysis in this research, in which a questionnaire survey was used to collect the quantitative data. At the same time, direct observation and key informant interviews were conducted to collect the qualitative data. Secondary information was obtained through literature reviews (articles, journals, reports, books), available online and official visits to the Nepal Tourism Board (NTB), Tourism Office in Pokhara, and ecosystem-based adaptation (EbA) Project Management Unit (Forestry Complex) in Kathmandu. The questionnaire survey was conducted using a purposive sampling method due to a lack of pre-information of the potential participants. There were 46 households involved in community homestay business while 3 families were engaged in individual homestay business. Few unregistered/undocumented homestays (probably 3-5 homestays) were also present (as per KII participants). No information was available to precisely know how many hotels were present because of ambiguity surrounding what constitutes a "hotel." Every source had different answers since even some local eateries would constitute "hotels" in the local language. However, since most hotels were concentrated around Ghatichinna, Bhanjyang, and Bhadaure Deurali, hotel owners from those areas were contacted for a questionnaire survey. A total of 122 tourism stakeholders (52 foreign tourists, 30 hoteliers, and 40 homestay owners) for questionnaire survey and 5 key informants (P1-non-governmental organization project member, P2-local homestay leader and owner, P3-local homestay owner and leader at Damdame, P4-youth club member and a homestay owner, and P5-local leader of Bhadaure-Tamagi village) were taken for data collection, and $100 \%$ of questionnaires were completed and collected most 
likely due to in-person follow-up in the initial field visit. After communicating through phone calls with many stakeholders in the area, just two additional key informant interviews (with P6-homestay owner and P7-local leader) were possible. They were interviewed in October 2020 to get the status of the ecotourism business after COVID-19. Questions related to probable ecotourism sites, the number of visitors staying in their lodge, earnings from their business, and maximum accommodation capacity of their business were asked to the hoteliers and homestay owners. But, questions related to the country of origin, the length of stay, expenditure in each trip, age, occupation, and preferred season of visit, was asked to the visitors. Also, questions related to homestay after COVID-19, a coping mechanism, recovery status, financial support from the government, and their future strategies were asked to P6 and P7. The collected data were coded and entered in Microsoft Office Excel for further analysis.

A checklist was used for key informant interviews (KII) to verify the information gathered from hoteliers and homestay owners and get detailed information about the SWOT framework. KII was moderated by one researcher, and data were noted by another member of the research in the field diary. Notes were taken during the phone interview of P6 and P7. Later, the collected information was compiled thematically and described in the report in different sections.

Data on tourist numbers and tourism revenue collected from hotels and homestays were used to measure tourism demand for the Bhadaure-Tamagi village's ecotourism product. The primary sources of this data were the businesses' guest logbooks. Similarly, data on hotels/homestays/lodges' capacity were used to measure maximum accommodation capacity. To draw the relationship between tourism demand and accommodation capacity in Bhadaure-Tamagi village, the maximum available annual data on tourist arrivals and the number of beds available there for the year 2011 to 2013 were collected from Tourism Office, Pokhara. All the collected data were entered into Excel spreadsheets for graphical and tabular analysis. Finally, the insights gained through various interviews with the stakeholders on the advantages and limitations of ecotourism in the Bhadaure-Tamagi village were analyzed using the SWOT framework. The information collected after COVID19 was discussed separately at the end of the results and discussion section. The refined framework can be presented as a three-dimensional diagram (Fig. 2).

\section{LEVELS}

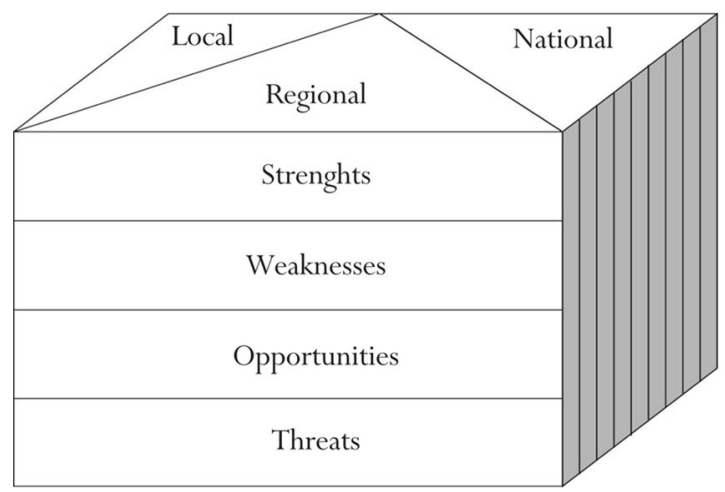

\section{ASPECTS}

Social,

Cultural,

Economic,

Geographic,

Political,

Environment,

Planning,

Psychology,

Infrastructure

Fig. 2 Three-dimensional SWOT analysis (Collins-Kreiner \& Wall, 2007) 


\section{Results and discussion}

\subsection{Major attractions of the site}

All the questionnaire survey respondents perceive that cultural and natural aspects were the major attractions of the area, which was verified by interviews with key informants. A scenic view of mountains, sunrise, and sunset from Panchase Peak $(2517 \mathrm{~m})$, beautiful landscape view of the Phewa lake, mountains, local villages, and Harpan valley from Bhanjyang (2066 m), Panchase lake, and diversity of flora and fauna for observation and research, was the major natural aspects of the area. The culturally rich Gurung village of Sidane and Bhadaure Deurali providing accommodation facilities, Panchase Dham, the temple of Lord Shiva, Hom Kunda, Balaji Panchayan temple, Bouddha Stupas, and pilgrimage and local market during Balachaturdashi festival are some of the religious and cultural attractions of the area. Rather than identifying ecotourism destinations as a whole in the study area, Kumari et al. (2010) adopted a different approach by categorizing other sites within the study area in terms of their ecotourism potential: $93.56 \mathrm{~km}^{2}$ area as very high potential followed by $620.81 \mathrm{~km}^{2}, 307.08 \mathrm{~km}^{2}$, and $145.18 \mathrm{~km}^{2}$ as having high, moderate, and low potentials, respectively, for ecotourism in the West District of Sikkim.

It can be observed that the cultural aspect is one of the primary attraction sources of Panchase, similar to the study of Yang (2019) in Yiren Town of China. These types of cultural aspects also respect the natural environment (Atun et al., 2019). Sometimes, souvenirs are taken as a part of cultural identity (Elomba \& Yun, 2018). The natural aspect was another vital aspect of Panchase, similar to Montaguti \& Mingotto (2015) study and Schirpke et al. (2020) in Italy. Both culture and nature were attracting tourists, similar to the study of Salinas et al. (2018) in Cuba; Dong et al. (2015) in China; Acharya \& Halpenny (2013) in Barpak, Nepal; K C et al. (2015) in Ghandruk, Nepal; K C et al. (2020) in Golaghat and Ghalegaun of Nepal, and Zhao \& Jia (2008) in the Lugu Lake region, China.

\subsection{Minimum tourism demand}

For the year 2013, 20,840 tourists stayed at least one night in either homestays or hotels of Bhadaure-Tamagi village of the Panchase area. When compared with the tourism demand in terms of tourist arrivals of Macedonia's hilly-mountain areas-which stands at 68,809 for the year 2012 (Petrevska, 2013), the tourist demand for Panchase Area does not look much encouraging. The annual tourist arrival in the park of Appennino Lucano and Sile River park of Italy was 52,000 and 250,000, respectively (Montaguti \& Mingotto, 2015). The annual tourist arrival in Cuba was 4.1 million in 2016 (Salinas et al., 2018), and the average daily visitor in the castle of Nafpaktos, Western Greece in 2011 was 6600 (Iliopoulou-Georgudaki et al., 2017). In Bhadaure-Tamagi village, the tourism demand in terms of revenue generated was estimated as NRs. 1,222,000 or US $\$ 10,763.67$ (US $\$ 1=$ NRs. 113.53 as of foreign exchange of 7 th October 2019). The majority of these tourists stayed at Bhadaure-2, which had a relatively larger number of homestays and hotels/lodges (Fig. 3). Bhadaure-9 presents a rather interesting figure where hotels/lodges/guest houses singlehandedly command the figure of 6,600 tourist arrivals.

Tourism revenue in Panchase is less than that of the Eastern Arc Mountains of Tanzania, where the value stands at US $\$ 214,285$ (Okayasu, 2008). Also, it is less than Viadana (56,970 Euro) and Stella (2,553,970 Euro) of Italy (Schirpke et al., 2020). Specific values have not been considered in this study, such as tour guide fees and the tour costs, protected 


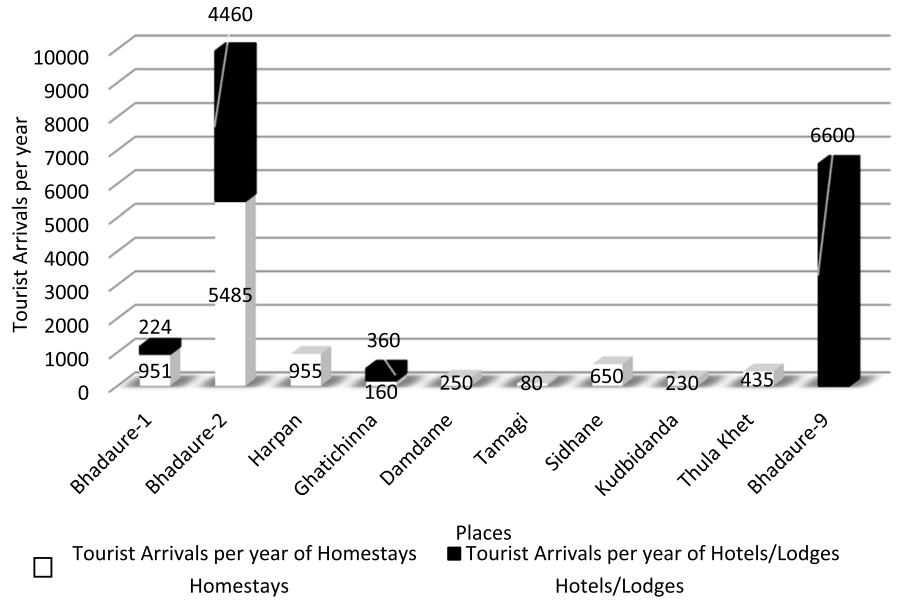

Fig. 3 Minimum tourism demand of different places of Bhadaure-Tamagi village

area fees, vehicle fees, parking and guide fees, or camping fees. It was due to the lack of recorded data of these components. This means that the minimum estimate established in this study could be well below the actual revenues. Looking at the tourism sector globally, this value of Bhadaure-Tamagi village is less by a considerable margin where London leads the table with the US \$19 billion in 2014 (Statista, 2015).

\subsection{Maximum accommodation capacity}

From the collected hotel data, the maximum bed-night capacity of Bhadaure-Tamagi village was estimated at a total of 318 bed nights per day (116,070 bed nights per annum). This amounts to an estimated annual maximum achievable income (which is only possible provided there is $100 \%$ occupancy whole year round) of over NRs. 58,035,000 or US $\$ 511,186.47$ for the Bhadaure-Tamagi as a whole. Among the places where tourist accommodation is available, the highest capacity was measured for Bhadaure-2 (Fig. 4). Bhadaure-9 (Bhanjyang) has the second-highest capacity due to an extensive range of guest houses/lodges/hotels despite being without any homestays. In a countrywide study by Sedai (2013), 69,040 bed nights per day were recorded in 2,604 tourist accommodation enterprises in fifteen major and five minor tourist sites selected for study across Nepal in 2010. In a similar study conducted in Romania by Popescu \& Plesoianu (2017), the whole country had an accommodation capacity of 328 thousand beds in 2015, 311 thousand beds in 2014, and 306 thousand beds in 2013.

From a collected visitor's data in Bhadaure-Tamagi, there is about $20 \%$ occupancy in accommodation businesses in 2013 , which needs to increase to make the businesses sustainable. This is too low for running a hospitality business, considering that the national average of even the luxury five-star hotels of Nepal is $58.85 \%$, according to primary statistics of MoCTCA as cited in Royal Mountain Travel (2014). In the hospitality sector, an occupancy rate greater than 40 percent is considered "survival," a rate higher than 60 percent is "good." An occupancy rate anywhere below $60 \%$ is a troubling situation for the investors, according to the Hotel Association Nepal leader, published in Royal Mountain Travel (2014). However, compared to just a 3\% hotel occupancy in the Eastern Arc 


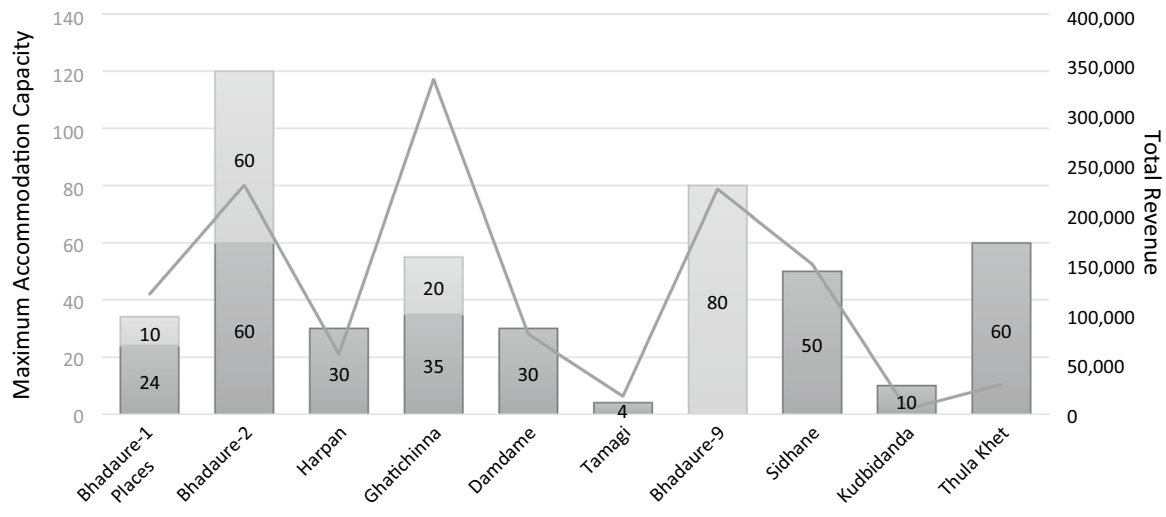

$\square$ Maximum accomodation capacity of Homestays $\square$ Maximum accomodation capacity of Hotels/Lodges Total revenue

Fig. 4 Maximum accommodation capacity of Bhadaure-Tamagi village

Mountains of Tanzania in 2007 (Okayasu, 2008), this is still an encouraging figure for Bhadaure-Tamagi village. It is also supported by the fact that there was a decrease in the hospitality sector's business throughout Nepal in 2013 (Royal Mountain Travel, 2014).

According to the KII participants, another reason for the low occupancy of accommodation facilities in Bhadaure-Tamagi village might be its closeness to Pokhara, a major tourist destination of Nepal. Only a few percolated tourists from Pokhara go there. So, tourism in Panchase Area as a whole is, to a large extent, dependent on the tourism market of Pokhara, similar to that of Cuba dependent on the United States tourism market (Salinas et al., 2018). Meanwhile, the demand for tourism in ACAP, the world-famous long-duration trekking destination adjacent to Panchase Area, was 113,459 in 2013, which rose to 114,187 in 2016 and 158,578 in 2017 (Republica, 2018). Mushrooming of cheaper homestays is blamed for the occupancy dip in hotels, resorts, and guesthouses around the country, which was not the case in Bhadaure-Tamagi village, where homestays welcome more guests than hotels in overall, according to the KII participants.

\subsection{Relationship between tourism demand and accommodation capacity}

For the relationship between minimum tourism demand and maximum accommodation capacity (Table 1), the data for only homestays in Bhadaure-Tamagi village registered at

Table 1 Relationship between Maximum Accommodation Capacity and Minimum Tourism Demand

\begin{tabular}{lll}
\hline Year & No. of Tourists & $\begin{array}{l}\text { No. of } \\
\text { beds } \\
\text { available }\end{array}$ \\
\hline 2011 & 17,200 & 44 \\
2012 & 19,000 & 94 \\
2013 & 21,100 & 97 \\
\hline
\end{tabular}

Source: Tourism Office, Pokhara \&(2014) 
the Tourism Office, Pokhara, were included. The process of registration began in 2011, and accommodation data from 2011 to 2013 only was available.

The relationship between minimum tourism demand and maximum accommodation capacity (Table 1) shows a rise in the initial year, slowing down later and approaching stagnation. This indicates that the homestay business is stabilizing and approaching saturation. To rejuvenate the business again, the ecotourism business needs to diversify its ecotourism products and services (Zhao \& Jia, 2008). This trend of ecotourism development appears, more or less, in line with Butler's model (1980), which shows how any tourist resort may grow in size. The model suggests that all resorts go through the same process of seven stages, viz. exploration, involvement, development, consolidation, stagnation, and then either decline or rejuvenation (Butler, 1980). A similar study by Popescu and Plesoianu (2017) in Romania showed a general increasing trend in tourist arrivals from 6972 thousand to 9930 thousand in the period 2007-2015 and in the same period, the accommodation capacity followed a similar trend to keep up with the demand by increasing from 284 thousand beds available to 328 thousand beds available which shows that the tourism development in Romania is still in the development stage and will continue to grow for some years. In another study by Zaharia et al. (2008) in Suceava County, Romania, the evolution of tourist accommodation capacity and tourist arrival numbers from the year 2000 to 2007 is shown where the number of accommodation places jumps from 5269 to 7012 in the same course of time when the number of tourist arrivals increased from 153 to 211 thousand. This increasing trend of accommodation capacity in tandem with tourism demand shows that tourism is still developing and continue to be so in years to come until it reaches the consolidation stage.

\subsection{Tourist characteristics}

From the visitor survey, the characteristics of the tourist visiting Panchase, such as the country of origin, average length of stay, spending per trip, age groups, occupation, and preference season for a visit were assessed.

\subsubsection{Continent of origin}

The highest proportion of foreign tourists was of European origin, followed by Asian nationalities (Fig. 5). These results contrast with national records, where tourists from India alone consistently topped the list of tourist arrivals for many years (MoCTCA, 2019). Indian tourists are more inclined towards Nepal's Hindu religious sites than the natural landscape, so their number is less compared to Nepal's overall tourist data. Indian tourists comprise 16.57\% of Nepal's tourist arrivals in the year 2018 (MoCTCA, 2019). There were many German tourists in Australia and Italy, whereas the British were the significant tourists for France (Yamaura \& Thompson, 2015). 
Fig. 5 Foreign tourist composition by continent of origin (in \%)

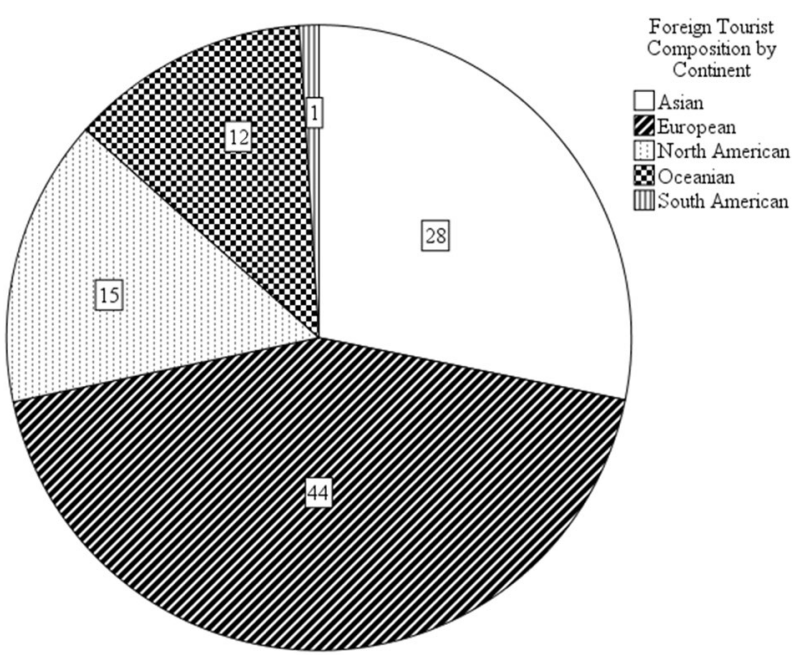

\subsubsection{Average length of stay}

The average length of stay of surveyed tourists was 12 days. The male tourists were found to spend 4 days less than female tourists (Fig. 6). The average length of stay was slightly lower than the national average of 12.60 for 2013 and 2017, which slightly decreased to 12.4 days in 2018 (MoCTCA, 2019). The average length of stay of tourists in Luxembourg was 2.3 days in the year 2013, which declined to 2.1 days for the year 2019 (Statistics Portal, 2020).

\subsubsection{Spending per trip}

The majority of tourists were spending US \$1000-5000, followed by those paying the US \$500-1000 (Fig. 7). Most of the expenditure was for air transport, so the spending on the destination was between the US \$100 and the US \$1000 depending upon tourists'

Fig. 6 Average length of stay of foreign tourists by gender

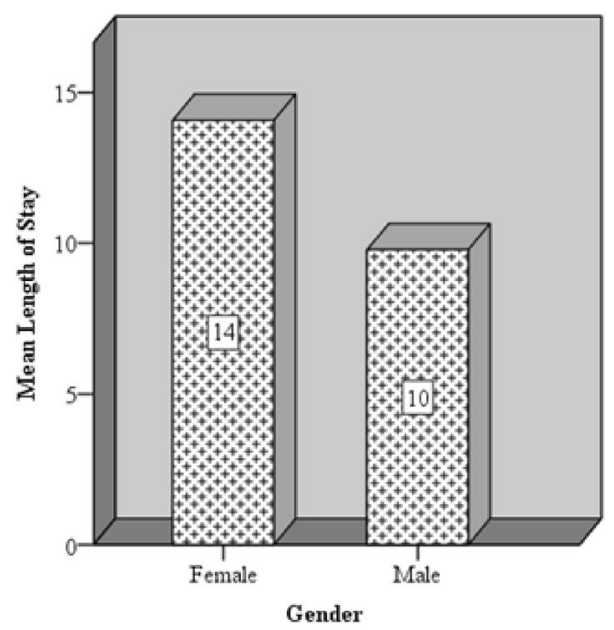


Fig. 7 Number and percentage share of spending per trip of foreign tourists

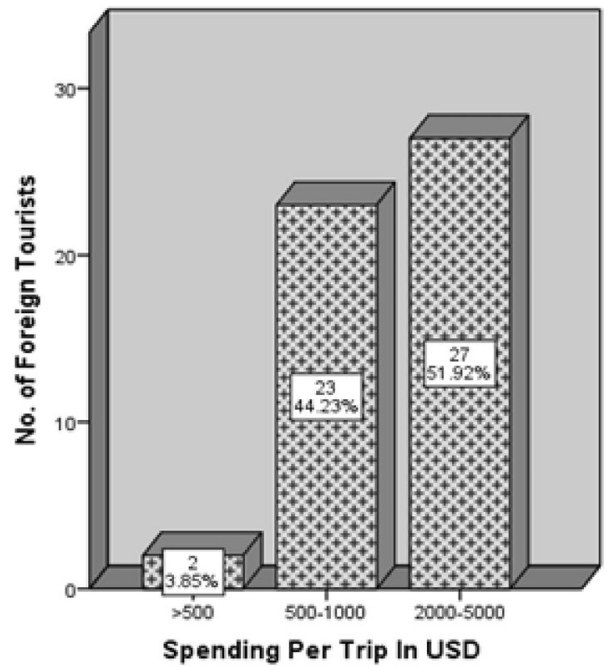

origin. While spending per trip was not available on national records, the daily expenditure for the year 2013 for foreign tourists in Nepal was the US \$42.8, and in 2017, it was US $\$ 54$ (MoCTCA, 2019). In the same year, the average spending per trip of foreign tourists to Greece was 604.2 euros ( 1 euro=the US \$1.3759 as of foreign exchange of 2014 May 9) while it came down five years later to 519.6 euros in 2018 (Kathimerini, 2019) (1 euro $=$ US $\$ 1.10$ as of foreign exchange of 2018 October 09).

\subsubsection{Age groups}

From the survey, the majority of foreign tourists were between 31 and 40 years of age, followed by 21-30 years of age (Fig. 8). In 2017, the percentage of tourists in the 31-45 age

Fig. 8 Foreign tourist composition (in \%) by age groups (in years)

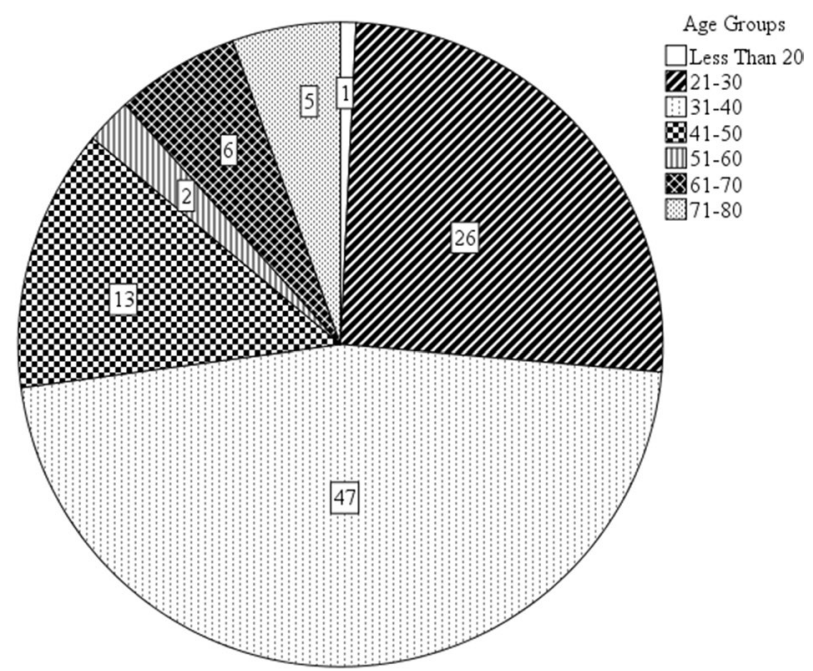


Fig. 9 Number of foreign tourists by occupation

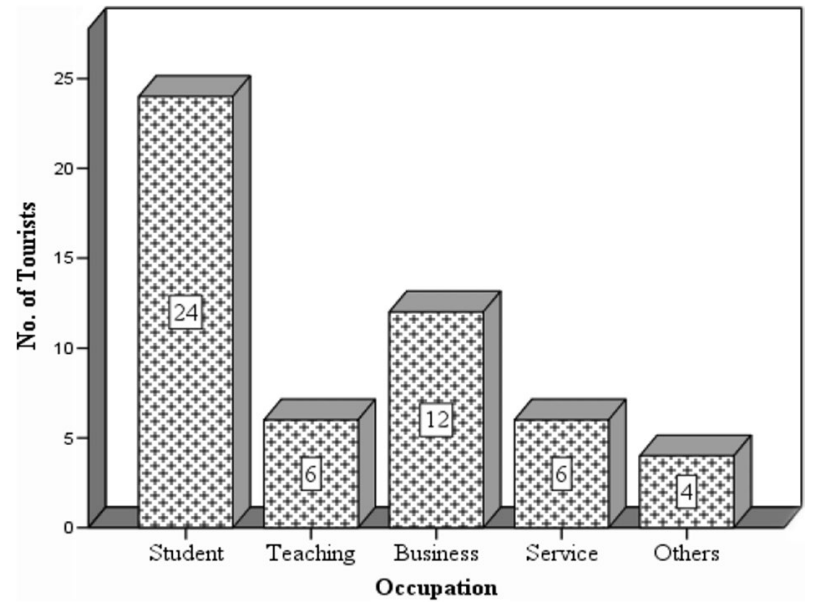

group was 30.7\%, and that of the 46-60 age group was 25.9\% (MoCTCA, 2019). In Yiren Town of China (Yang, 2019), the city of Cuenca, Ecuador (Serrano López et al., 2019), Korea (Elomba \& Yun, 2018), and India (Verma \& Chandra, 2018), there were a higher number of younger adult tourists.

\subsubsection{Occupation}

It was observed that most tourists (46.15\%) were often budget travelers and backpackers for study purpose and nature travel, which is followed by business people (Fig. 9). The backpacker's number was also higher in the study of the heritage City of Cuenca, Ecuador (Serrano López et al., 2019). This pattern was also observed in visitors at Cox's Bazar in Bangladesh, where $83.5 \%$ out of 200 respondents were students (Alarape et al., 2015). However, tourists visiting Dal Lake of Kashmir, India gave a different observation where $49 \%$ of them were employees followed by businesspersons who represented $22 \%$ of the total visitors (Yousuf \& Ali, 2018), while there were a higher number of people involved in the business in the study of Verma \& Chandra (2018) in India.

\subsubsection{Preference season for visit}

It was observed that most tourists' preference season was summer followed by autumn (Fig. 10). Twelve of the tourists interviewed reported feeling comfortable visiting at any season. However, considering traveling Nepal as a whole, the most favorable season falls in September to November when the weather is pleasant, and visibility is high (Sharma et al., 2013). In the Yiren Town of China, the peak tourist season was summer (Yang, 2019). Likewise, in Australia, the summer season falling on December, January, and February months, is the season of preference for tourists due to warmer weather and organization of popular sports events for tourists especially from the northern hemisphere where there is winter in those months (Auto \& General Services Pty Ltd, 2019).

Assessing the characteristics of a tourist is vital for running a tourism business sustainably in any tourism destination. Different tourists have different choices and demands during 
Fig. 10 Number of Foreign Tourists by Season of Preference

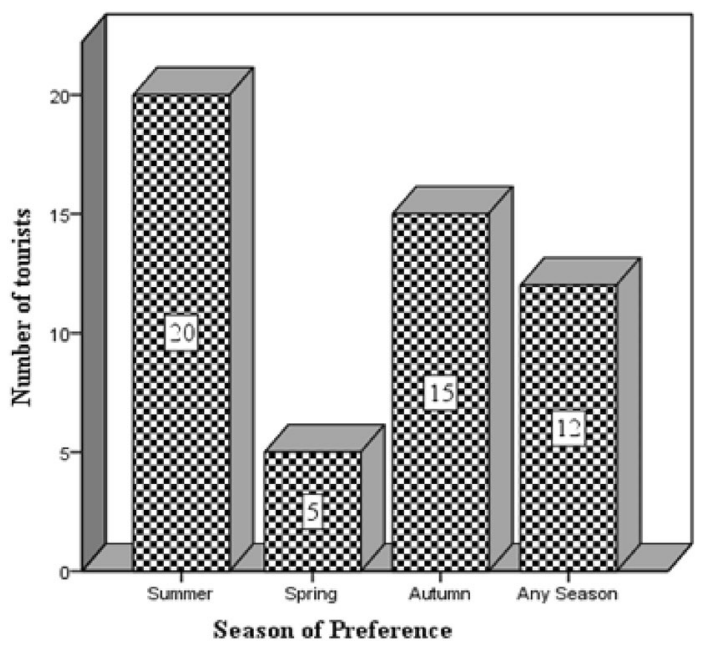

their travel. It is crucial to know their preferences and satisfy them, so they will have positive perceptions and have future intention to come back again and recommend the place to their friends and relatives.

\subsection{Status of ecotourism services and enterprise}

The findings of ecotourism's status and potential at national, regional, and local levels are shown below. Each result is illustrated using SWOT analysis as described in the framework in Fig. 2.

\subsubsection{National level}

The status of ecotourism is evaluated using SWOT analysis, as illustrated in Table 2.

\subsubsection{Regional Level}

The status of ecotourism at the regional level is illustrated using SWOT analysis in Table 3.

\subsubsection{Local Level}

The status of ecotourism at the local level (Bhadaure-Tamagi village) is illustrated using SWOT analysis in Table 4.

Although both internal factors (strengths and weaknesses) and external factors (opportunities and threats) play a vital role in the development of the tourism industry, external ones like unstable political situations, e.g., war, conflict, riots, and strikes, are crucial factors particularly in case of Nepal where tourism industry frequently suffers from frequent riots and strikes called by political parties and their sister organizations. At the same time, it has already gone through a decade-long phase of Maoist armed insurgency from 1996 to 2006. 


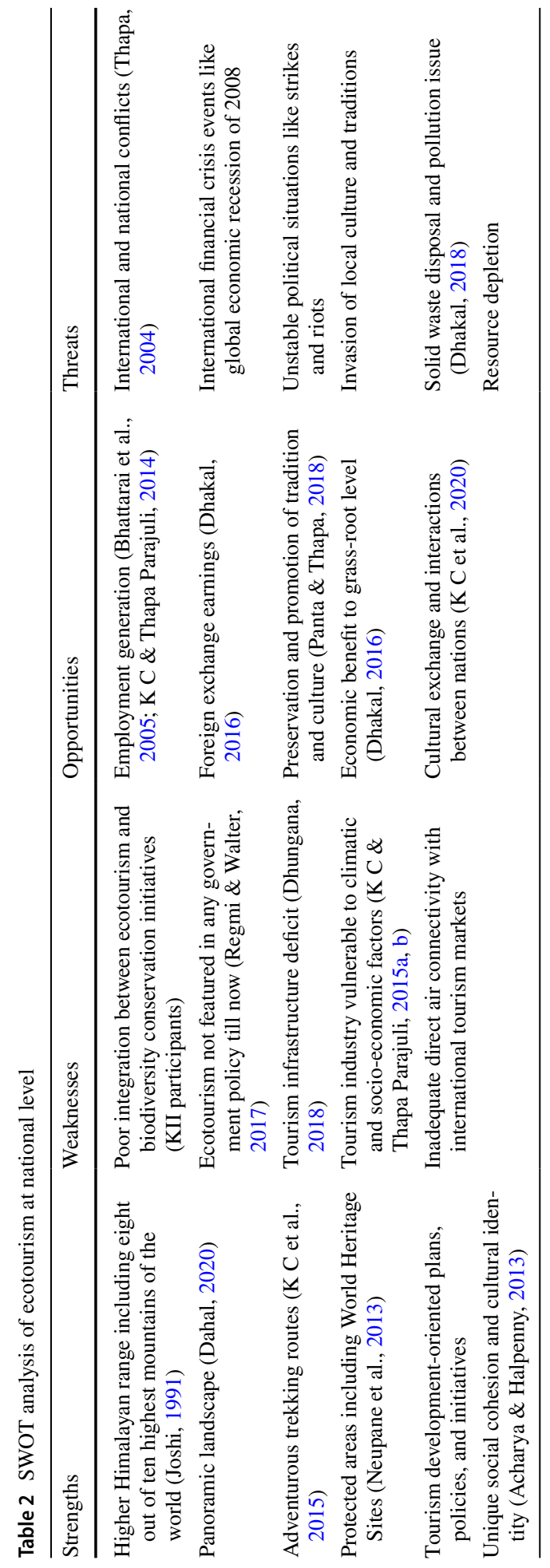




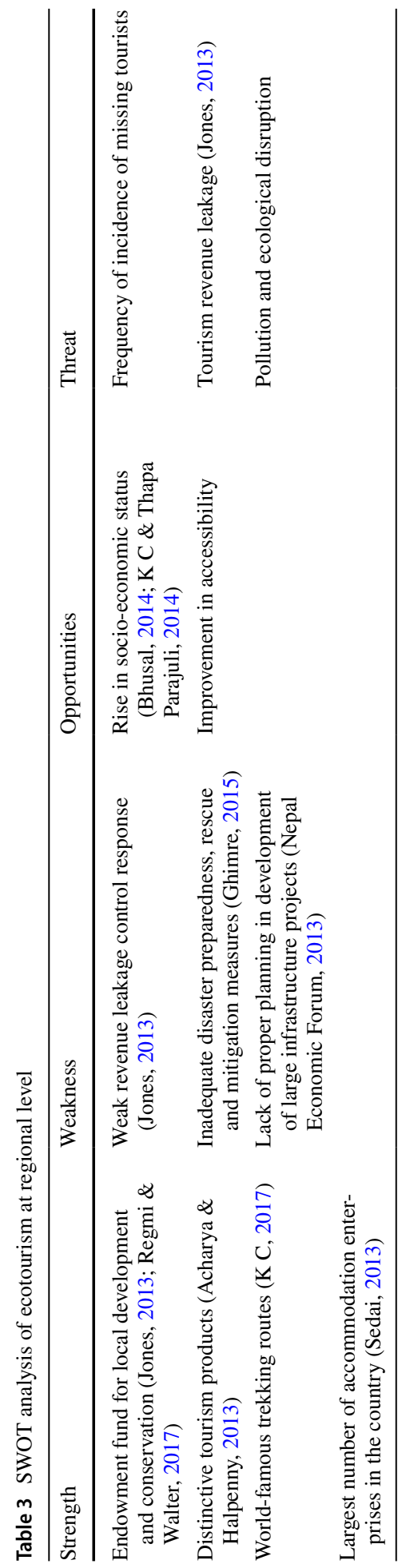




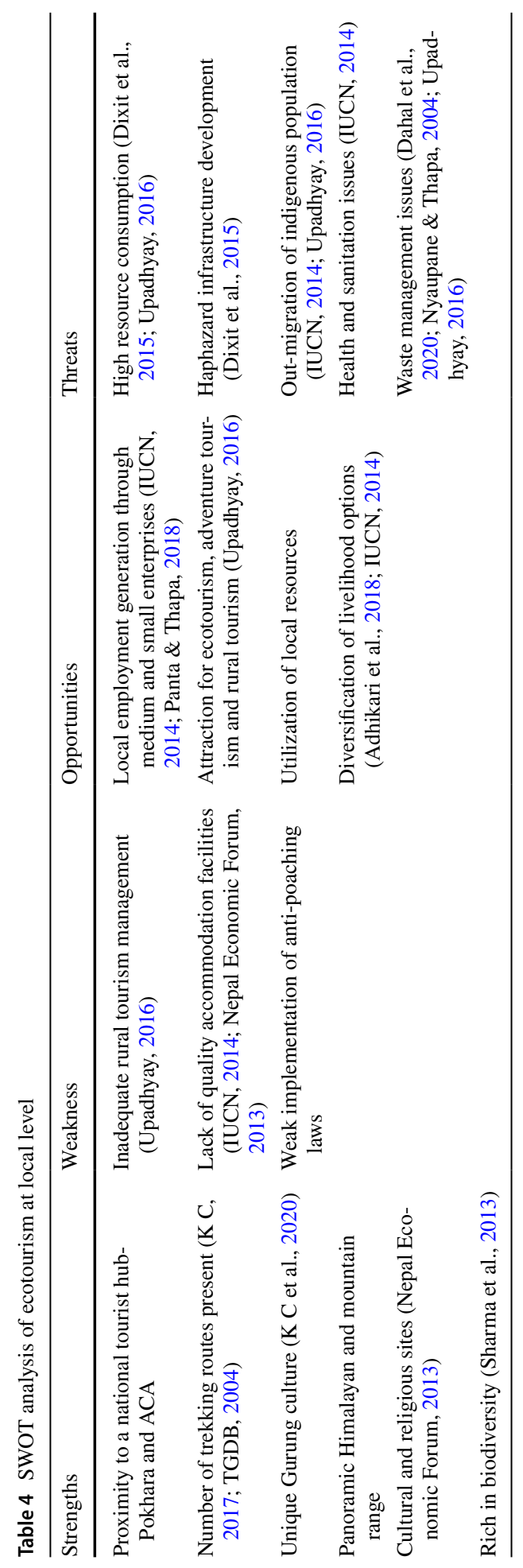


The primary strength of the Panchase region lies in its ability to offer unique tourism products that are a blend of natural and cultural resources. Being close to a major tourist city, Pokhara, the Panchase region also serves as a refuge away from city noises and congestion in a natural environment. The area also offers a stay at its homestays, which is also a source of education about the rural lifestyle and livelihood. The homestays also provide visitors to watch their traditional cultural performances, which further enhances the visitors' knowledge about the local culture (from KII participants). So, tourism in the Panchase region is a distinct combination of ecotourism and rural tourism. However, revenue leakage control could be a significant roadblock towards further tourism development of the area. Because visitors already make the majority of travel payments to trekking and travel agents in Pokhara, the region receives fewer tourism revenues than what it actually could command (from KII participants). Unless the Panchase Region itself can establish its own brand image as a major tourist destination of Nepal and investments to increase its accessibility, the revenue leakage will continue to plague its tourism enterprise.

Unlike other villages of the Panchase region, Bhadaure-Tamagi has a predominantly indigenous Gurung population, making it an attractive destination for experiencing the unique Gurung culture. Also, most of the trekking routes leading to the Panchase Peak, i.e., 5 out of 7 trekking route options mentioned in TGDB (2004), pass through BhadaureTamagi, offering it a unique opportunity to economically benefit from the hospitality and tourism businesses providing employment opportunities to the local youths. In fact, most of the accommodation facilities, such as homestays and small hotel businesses in Bhadaure-Tamagi, are gaining more popularity than those in other villages in the Panchase area. However, the growing trend of out-migration by youths searching for education and employment to other major cities like Pokhara and Kathmandu or even abroad threatens to chip away the progress made in tourism of Bhadaure-Tamagi. This is especially true for Tamagi village, where fewer than five households remain while most others have abandoned their houses and left arable land fallow, giving it a near resemblance to a ghost town (from direct observation).

Few strengths, weaknesses, opportunities, and threats of this study were matching with the study of Akbulak and Cengiz (2014) in Troia Historical National Park of Turkey, Dong et al. (2015) in Shangri-La County, China, and Iliopoulou-Georgudaki et al. (2017) in Western Greece. Some of the challenges of Panchase were also similar to that of Cuba (Salinas et al., 2018). Utilizing the strengths and opportunities, weaknesses and threats should be minimized. It can be done by appropriately mobilizing the local community, private sector, and governmental sector towards sustainability (Atun et al., 2019). SWOT analysis at different levels should be prioritized before developing a tourism destination.

\subsection{Ecotourism after COVID-19 in the study area}

COVID-19 had disturbed different economic sectors, including travel and tourism, in 2020 (Carr, 2020). Many countries in the world declared partial or complete lockdowns to decrease their internal transmission of disease, including Nepal (Sah et al., 2020). This led to the cancelation of international flights and international travel and tourism. Many hotels and restaurants were closed due to the lack of tourists (Gössling et al., 2021). Also, travelers did not feel comfortable to travel due to social distancing rules. They have started giving health, hygiene, and safety (HHS) a top priority after COVID-19 (Hao et al., 2020). Many ecotourism destinations in Nepal could not run properly due to the lack of tourists 
(Shrestha, 2020; WWF Nepal, 2020). They have to depend on other traditional sources of income besides tourism during a complete and partial lockdown.

According to the key informants, ecotourism in the Panchase area had also suffered a lot after COVID-19. In the initial phase of complete lockdown (starting at the end of March), no tourist was seen enjoying the local ecotourism facilities. People were only allowed to travel for emergency purposes, and they were restricted to travel for recreation. Local people were also hesitant to meet with the stranger due to the risk of virus transmission. As the lockdown eases at the end of July, people were seen traveling around, but ecotourism facilities were minimal. Ecotourism entrepreneurs had no other work than working on their farm, which was the other primary income source. As of now, few ecotourists, religious pilgrims, and researchers are seen enjoying the facilities. Local ecotourism entrepreneurs are applying necessary health, hygiene, and safety (HHS) measures and social distancing during this time of the pandemic. But it is still difficult to sustain the ecotourism business in the area with the current tourist flow in the area.

Local ecotourism entrepreneurs are hopeful of recovery of tourism in the long-term after the COVID-19 threat is over. With the current state of virus transmission, they have less hope for its comeback shortly. They have not received adequate financial and technical support from the government in this time of hardship, and very few had approached to help them during this pandemic. To sustain their living, they have to rely on their farming and remittance send by their family members and relatives from foreign countries. They are also planning to continue the HHS measures and social distancing in future interactions with visitors.

\section{Conclusion and implications}

Natural and cultural components were the primary source of attractions in Panchase. Despite being rich in natural and cultural aspects, occupancy rates were low, which is inefficient for the tourism business's sustainability. It might be essential to address the preference of tourists to attract them again in the future. It is also true that there is ample space for the growth of the ecotourism business, for which it requires the promotion of destinations within Bhadaure-Tamagi village at the national level and international level. The SWOT analysis concluded that the people of Bhadaure-Tamangi village benefitted from the advent of ecotourism through various ecotourism products such as rich culture, tradition, biodiversity, beautiful scenery of mountain and forest landscapes, occasional festivals, etc.

It is also concluded that there are many opportunities where proper management of ecotourism in Bhadaure-Tamagi village with a clear and defined strategy, vision, mission, and objectives can improve and enhance ecotourism as a system and remain strategically competitive. Also, the policymakers should look towards welcoming tourists and not just backpackers because the tourism demand in terms of revenues is not high compared to tourist arrivals. For that, they should formulate policies to encourage the locals, especially the homestay owners, to diversify their tourism products to get tourists to spend more while also conducting tourism promotion activities. Now, COVID-19 had crossed all the boundaries and affected ecotourism. It has forced policymakers to rethink their ecotourism policy to overcome its challenges. In the meantime, local ecotourism entrepreneurs might have to apply a different strategy to sustain their ecotourism business. HHS measures need to be prioritized in their regular tourism business and their future promotional activities so that 
ecotourists will feel safe to enjoy their facilities. In this way, they can make the ecotourism business more sustainable in the long run.

As this study was conducted in only one tourism destination at a particular time duration with fewer samples, it is suggested to other researchers to perform a SWOT analysis and tourism carrying capacity studies in other potential ecotourism sites focusing on a large sample size for a more extended period of time. Researchers have tried their best to collect necessary information in one area at different times of 2013, 2014, and 2020. Still, there are different avenues for future research options in the country's other ecotourism destinations.

\section{Compliance with ethical standards}

Conflict of interest The authors reported no potential conflict of interest.

\section{References}

Acharya, B. P., \& Halpenny, E. A. (2013). Homestays as an alternative tourism product for sustainable community development: A case study of women managed tourism product in rural Nepal. Tourism Planning \& Development, 10(4), 367-387.

Adhikari, S., Baral, H., \& Nitschke, C. (2018). Adaptation to climate change in Panchase mountain ecological regions of Nepal. Environments, 5(3), 42.

Akbulak, C., \& Cengiz, T. (2014). Determining ecotourism strategies using A'WOT hybrid method: Case study of Troia Historical National Park, Çanakkale, Turkey. International Journal of Sustainable Development \& World Ecology, 21(4), 380-388.

Akça, H. (2006). Assessment of rural tourism in Turkey using SWOT analysis. Journal of Applied Sciences, 6(13), 2837-2839.

Alarape, A. A., Yager, G. O., \& Salman, K. K. (2015). Assessment of tourists' satisfaction and perception in Makurdi Zoological Garden, Benue state, Nigeria. Journal of Research in Forestry, Wildlife and Environment, 7(1).

Atun, R. A., Nafa, H., \& Türker, Ö. O. (2019). Envisaging sustainable rural development through 'contextdependent tourism': A case of northern Cyprus. Environment, Development and Sustainability, 21(4), 1715-1744. https://doi.org/10.1007/s10668-018-0100-8

Auto \& General Services Pty Ltd. (2019). Australian tourism statistics 2019.

Bălăcescu, A., \& Răbonţu, C. I. (2010). Statistical analysis of the touristic accommodation capacity and activity in Romania during 2000-2009. Annals of the University of Petroşani, 10(4), 19-26.

Beeler, B. G. (2000). Opportunities and threats to local sustainable development: Introducing ecotourism to Venado Island, Costa Rica. Lund University.

Beerli, A., \& Martín, J. D. . (2004). Tourists' characteristics and the perceived image of tourist destinations: A quantitative analysis-A case study of Lanzarote, Spain. Tourism Management, 25(5), 623-636. https://doi.org/10.1016/j.tourman.2003.06.004

Bhatia, A. (2013). SWOT analysis of Indian tourism industry. International Journal of Application or Innovation in Engineering \& Management, 2(12), 44-49.

Bhattarai, K., Conway, D., \& Shrestha, N. (2005). Tourism, terrorism and turmoil in Nepal. Annals of Tourism Research, 32(3), 669-688.

Bhusal, N. P. (2014). Role of tourism in local development: A case of Sarangkot Hill-Top in Pokhara, Western Nepal. The Third Pole: Journal of Geography Education. https://doi.org/10.3126/ttp.v8i0.11507

Butler, R. W. (1980). The concept of a tourist area cycle of evolution: Implications for management of resources. Canadian Geographer/Le GéographeCanadien, 24(1), 5-12.

Carr, A. (2020). COVID-19, indigenous peoples and tourism: A view from New Zealand. Tourism Geographies, 22(3), 491-502. https://doi.org/10.1080/14616688.2020.1768433

Chuan, A. S., \& Weng, C. N. (2010). Tourist characteristics at Tabing Salt Lick. World Applied Sciences Journal, 10(10), 1153-1159. 
Collins-Kreiner, N., \& Wall, G. (2007). Evaluating tourism potential: A SWOT analysis of the Western Negev. Israel. Turizam: MeđunarodniZnanstveno-StručniČasopis, 55(1), 51-63.

Dahal, B., K C, A., \& Sapkota, R. P. (2020). Environmental Impacts of Community-Based Home stay Ecotourism in Nepal. The Gaze: Journal of Tourism and Hospitality, 11(1), 60-80.

Dhakal, B. (2016). Analyzing Nepal's foreign exchange earnings from tourism using co-integration and causality analysis. American Journal of Mathematics and Statistics, 6(6), 227-232.

Dhakal, S. (2018, March 18). Waste from Everest region airlifted. The Himalayan Times.

Dhungana, S. (2018). Tourism will drive Nepal's economy in the future. The Himalayan Times.

Diamantis, D. (1999). The concept of ecotourism: Evolution and trends. Current Issues in Tourism, 2(2-3), 93-122.

Dickman, S. (1989). Tourism: An introductory text. Edward Arnold Publisher, ISBN: 0713183381.

Dixit, A., Karki, M., \& Shukla, A. (2015). Vulnerability and impacts assessment for adaptation planning in Panchase Mountain Ecological Region, Nepal, Kathmandu, Nepal: Government of Nepal, United Nations Environment Programme, United Nations Development Programme, International Union for Conservation of Nature, German Federal Ministry for the Environment. Nature Conservation, Building and Nuclear Safety and Institute for Social and Environmental Transition-Nepal.

Dong, M., Wu, D., Fu, X., Deng, H., \& Wu, G. (2015). Regional-scale analysis on the strengths, weaknesses, opportunities, and threats in sustainable development of Shangri-La County. International Journal of Sustainable Development \& World Ecology, 22(2), 171-177.

Elomba, M. N., \& Yun, H. J. (2018). Souvenir authenticity: The perspectives of local and foreign tourists. Tourism Planning \& Development, 15(2), 103-117.

Ganjali, S. (2014). Environmental and strategic assessment of ecotourism potential in Anzali Wetland using SWOT analysis. Caspian Journal of Environmental Sciences, 12(1), 155-165.

Ghimre, H. L. (2015). Disaster management and post-quake impact on tourism in Nepal. Journal of Tourism and Hospitality, 7, 37-57.

Gössling, S., Scott, D., \& Hall, C. M. (2021). Pandemics, tourism and global change: A rapid assessment of COVID-19. Journal of Sustainable Tourism, 29(1), 1-20. https://doi.org/10.1080/09669582.2020. 1758708.

Hadi, W. D., \& Prasetyo, E. A. (2020). Tourist characteristics, tourism product attributes, and tourist satisfaction on visiting tourism object of Rammang-Rammang Limestone Forest Park, Maros district of South Sulawesi, Indonesia. Russian Journal of Agricultural and Socio-Economic Sciences, 3(99), 3-8.

Hao, X., Cheng, S., Wu, D., Wu, T., Lin, X., \& Wang, C. (2020). Reconstruction of the full transmission dynamics of COVID-19 in Wuhan. Nature, 584(7821), 420-424. https://doi.org/10.1038/ s41586-020-2554-8.

Hernández-Méndez, J., \& Muñoz-Leiva, F. (2015). What type of online advertising is most effective for eTourism 2.0? An eye tracking study based on the characteristics of tourists. Computers in Human Behavior, 50, 618-625. https://doi.org/10.1016/j.chb.2015.03.017

Hong, C.-W., \& Chan, N.-W. (2010). Strength-weakness-opportunities-threats analysis of Penang National Park for strategic ecotourism management. World Applied Sciences Journal, 10(1), 136-145.

Iliopoulou-Georgudaki, J., Theodoropoulos, C., Konstantinopoulos, P., \& Georgoudaki, E. (2017). Sustainable tourism development including the enhancement of cultural heritage in the city of NafpaktosWestern Greece. International Journal of Sustainable Development \& World Ecology, 24(3), 224-235.

IUCN. (2014). Strengthening homestay business for diversifying livelihoods: Building local people's resilience against climate change in the Panchase Area (p. 4). International Union for Conservaton of Nature.

Jones, H. (2013). Entry points for developing tourism in Nepal: What can be done to address constraints to inclusive growth? [Research Paper]. Overseas Development Institute.

Joshi, R. B. (1991). Nepal: A paradise for the deaf? Sign Language Studies, 71(1), 161-168.

K C, A. . (2017). Ecotourism in Nepal. The Gaze: Journal of Tourism and Hospitality, 8, 1-19.

K C, A., \& Thapa Parajuli, R. B., (2014). Tourism and its impact on livelihood in Manaslu conservation area, Nepal. Environment, Development and Sustainability, 16(5), 1053-1063. https://doi.org/10. 1007/s10668-013-9512-7.

K C, A., \& Thapa Parajuli, R. B., (2015). Climate change and its impact on tourism in the Manaslu conservation area, Nepal. Tourism Planning \& Development, 12(2), 225-237. https://doi.org/10.1080/ 21568316.2014.933122.

K C, A., \& Thapa Parajuli, R. B. (2015). Tourism and its impact on livelihood in Manaslu Conservation Area, Nepal. Environment, Development and Sustainability, 16(5), 1053-1063.

K C, A., Ghimire, S., \& Dhakal, A. (2020). Ecotourism and its impact on indigenous people and their local environment: Case of Ghalegaun and Golaghat of Nepal. GeoJournal. https://doi.org/10.1007/ s10708-020-10222-3 
K C, A., Rijal, K., \& Sapkota, R. P. (2015). Role of ecotourism in environmental conservation and socioeconomic development in Annapurna Conservation Area, Nepal. International Journal of Sustainable Development \& World Ecology, 22(3), 251-258.

Kathimerini. (2019). Major drop in tourists' expenditure. Ekathimerini.com; Retrived from: https:// www.ekathimerini.com/240740/article/ekathimerini/business/major-drop-in-tourists-expenditure.

Kumari, S., Behera, M., \& Tewari, H. (2010). Identification of potential ecotourism sites in West District, Sikkim using geospatial tools. Tropical Ecology, 51(1), 75-85.

Mbaiwa, J. (2010). Review of tourism management models [Project Development Report]. http://lib.agu. edu.vn/images_old_lib/image_content_lib/management.pdf.

MoCTCA (2019). Nepal tourism statistics. (2018). Ministry of Culture. Tourism \& Civil Aviation.

Montaguti, F., \& Mingotto, E. (2015). Ecotourism in natural parks: An assured sustainable success? Tourist behavior, attractiveness and sustainable development issues in two Italian parks. Tourism Planning \& Development, 12(1), 99-110.

Moosavi, S., Safania, A., \& Soraei, S. (2013). Feasibility athletic abilities nature (ecotourism, sports) West Mazandaran using SWOT analysis. International Research Journal of Applied and Basic Sciences, 5(10), 1238-1244.

Murugan, A. (2007). Exploring the potential and usefulness of ecotourism in Puducherry with special reference to tourism and environment [Master Plan and Viable Project Report].

Neba, N. E. (2009). Ecological planning and ecotourism development in Kimbi Game Reserve, Cameroon. Journal of Human Ecology, 27(2), 105-113.

Nepal Economic Forum. (2013). Promoting community managed ecotourism in Chitwan Annapurna Landscape and Terai Arc Landscape. Nepal Economic Forum. https://wwfasia.awsassets.panda. org/downloads/eco_tourism_for_website__copy_1.pdf.

Neupane, R., \& K C, A., \& Pant, R. R. (2013). Assessing tourism potential in Bhaktapur Durbar Square, Nepal. International Journal of Environment, 2(1), 250-261.

Nikolaou, I. E., \& Evangelinos, K. I. (2010). A SWOT analysis of environmental management practices in Greek mining and mineral industry. Resources Policy, 35(3), 226-234.

Nyaupane, G. P., \& Thapa, B. (2004). Evaluation of ecotourism: A comparative assessment in the Annapurna Conservation Area Project, Nepal. Journal of Ecotourism, 3(1), 20-45.

Okayasu, S. (2008). The status of ecotourism in the Eastern Arc Mountains of Tanzania [Thesis].

Ouerfelli, C. (2008). Co-integration analysis of quarterly European tourism demand in Tunisia. Tourism Management, 29(1), 127-137.

Panta, S. K., \& Thapa, B. (2018). Entrepreneurship and women's empowerment in gateway communities of Bardia national park, Nepal. Journal of Ecotourism, 17(1), 20-42.

Peršurić, A. S. I., \& Težak, A. (2009). The influence of socio-demographic characteristics of tourists on their interest for organic food in Istria, Croatia. Agricultural Economics, 10(6), 296-305.

Petrevska, B. (2013). Empirical evidence of tourism planning in hilly-mountain areas. 479.

Popescu, A., \& Plesoianu, D. (2017). Analysis of accommodation demand/offer in Romania's tourism. Scientific Papers Series Management, Economic Engineering in Agriculture and Rural Development, 17(3), 339-346.

Regmi, K. D., \& Walter, P. (2017). Modernisation theory, ecotourism policy, and sustainable development for poor countries of the global South: Perspectives from Nepal. International Journal of Sustainable Development \& World Ecology, 24(1), 1-14.

Republica. (2018). Annapurna region welcomed record 158,600 trekkers in 2017. Retrieved from https:// myrepublica.nagariknetwork.com/news/35407/.

Royal Mountain Travel. (2014, June 18). Hotel occupancy dips in 2013-NewsNews. Royal Mountain Travel.

Sah, R., Sigdel, S., Ozaki, A., Kotera, Y., Bhandari, D., Regmi, P., et al. (2020). Impact of COVID-19 on tourism in Nepal. Journal of Travel Medicine. https://doi.org/10.1093/jtm/taaa105.

Salinas, E., Mundet, L., \& Salinas, E. (2018). Historical evolution and spatial development of tourism in Cuba, 1919-2017: What is next? Tourism Planning \& Development, 15(3), 216-238.

Sariisik, M., Turkay, O., \& Akova, O. (2011). How to manage yacht tourism in Turkey: A SWOT analysis and related strategies. Procedia-Social and Behavioral Sciences, 24, 1014-1025.

Sayyed, M. R. G., Mansoori, M. S., \& Jaybhaye, R. G. (2013). SWOT analysis of Tandooreh National Park (NE Iran) for sustainable ecotourism. Proceedings of the International Academy of Ecology and Environmental Sciences, 3(4), 296-305.

Schirpke, U., Scolozzi, R., Da Re, R., Masiero, M., Pellegrino, D., \& Marino, D. (2020). Enhancing outdoor recreation and biodiversity through payments for ecosystem services: Emerging potentials from selected Natura 2000 sites in Italy. Environment, Development and Sustainability, 22(3), 2045-2067. 
Sedai, R. C. (2013). Tourist accommodation facilities in the major tourist areas of Nepal. Nepal Tourism and Development Review, 1(1), 102-123. https://doi.org/10.3126/ntdr.v1i1.7374

Serrano López, A. L., Freire Chaglla, S. A., Espinoza-Figueroa, F. E., Andrade Tenesaca, D. S., \& Villafuerte Pucha, M. E. (2019). Modeling of tourist profiles with decision trees in a world heritage city: The case of Cuenca (Ecuador). Tourism Planning \& Development, 16(5), 473-493. https://doi.org/10. 1080/21568316.2018.1501731

Sharma, B. K., Timalsina, K., Rai, R., Maharjan, S. K., Joshi, A., \& Rakhal, B. (2013). Biodiversity resource inventory: Ecosystem assessment of BhadaureTamagi VDC. Kaski.

Sharma, S., \& Bhattarai, U. (2012, October 2). Homestay tourism in Nepal: Opportunities and challenges. Homestay tourism in Nepal: Opportunities and challenges, Kathmandu, Nepal. Retrieved from https:// www.academia.edu/6800362/Home_Stay_Tourism_in_Nepal_Opportunities_and_Challenges.

Shrestha, P. M. (2020, March 4). Nepali economy starts to feel the pinch as coronavirus spreads. The Kathmandu Post. https://kathmandupost.com/national/2020/03/04/nepali-economy-starts-to-feel-the-pinchas-coronavirus-spreads.

Silva, R., Breda, Z., Brandão, F., \& Costa, R. (2020). An analysis of the shopping behaviour of international tourists: The case of Porto. Springer.

Song, H., Li, G., Witt, S. F., \& Fei, B. (2010). Tourism demand modelling and forecasting: How should demand be measured? Tourism Economics, 16(1), 63-81.

Soukiazis, E., \& Proença, S. (2008). Tourism as an alternative source of regional growth in Portugal: A panel data analysis at NUTS II and III levels. Portuguese Economic Journal, 7(1), 43-61.

Statista. (2015). Statistics and facts on the global tourism industry. Global Tourism Industry - Statistics \& Facts. Retrieved from https://www.statista.com/topics/962/global-tourism/.

Statistics Portal. (2020). Average length of stay by touristic region and country of residence (hotels and similar establishments) 2011-2019.

TGDB. (2004). Panchase rural tourism master plan. Tara Gaon Development Board.

Thapa, B. (2004). Tourism in Nepal: Shangri-La's troubled times. Journal of Travel \& Tourism Marketing, $15(2-3), 117-138$.

Timmer, V., \& Juma, C. (2005). Taking root, biodiversity conservation and poverty reduction come together in the tropics: Lessons learned from the Equator Initiative. Environment, 47(4), 24-44.

Travers, R. \& LaPaz Group (2012). Tourism strategy and action plan for the Prespa lakes basin 2012-2016. Retrieved from www.undp.org.dam/doc/tourism strategy.

UNEP. (2020). Tourism I UNEP - United Nations Environment Programme webpage

UNWTO. (2020, January 19). World Tourism Barometer N 18 January 2020 | World Tourism Organization. Retrieved from https://www.unwto.org/world-tourism-barometer-n18-january-2020.

Upadhyay, P. (2016). Envisaged for sustainable rural development: Viability and challenges of rural tourism in Nepal. REPOSITIONING The Journal of Business and Hospitality, 1(1), 37-52.

Verma, V. K., \& Chandra, B. (2018). An application of theory of planned behavior to predict young Indian consumers' green hotel visit intention. Journal of Cleaner Production, 172, 1152-1162.

WWF Nepal. (2020). COVID and conservation: We can't wait to welcome you to Nepal again. Retrieved June 21, 2020 from http://tigers.panda.org/news/covid-conservation-we-cant-wait-to-welco me-you-to-nepal-again/.

Yamaura, K., \& Thompson, A. (2015). Analysis of tourism demand model across European source countries. Tourism Planning \& Development, 12(2), 145-154.

Yang, L. (2019). Cultural tourism in a replicated old town: Tourists' views. Tourism Planning \& Development, 16(1), 93-111.

Yousuf, T., \& Ali, M. (2018). Tourist satisfaction, environmental concerns and tourism in and beyond Dal lake, Kashmir. Journal of Tourism \& Hospitality, 7(2), 349.

Zaharia, M., Hapenciuc, C. V., \& Gogonea, R.-M. (2008). Analysis of the correlation between the existing accommodation capacity and the number of tourists arrived in Suceava county structures of touristic reception. Revista de Turism-Studii Si Cercetari in Turism, 5, 43-48.

Zhao, J., \& Jia, H. (2008). Strategies for the sustainable development of Lugu Lake region. The International Journal of Sustainable Development and World Ecology, 15(1), 71-79.

Zhuang, H., Lassoie, J. P., \& Wolf, S. A. (2011). Ecotourism development in China: Prospects for expanded roles for non-governmental organisations. Journal of Ecotourism, 10(1), 46-63.

Publisher's Note Springer Nature remains neutral with regard to jurisdictional claims in published maps and institutional affiliations. 